\title{
プラン文書に着目したホーチミン市の都市マスタープランの変遷に関する研究 A STUDY ON TRANSFORMATION OF URBAN MASTER PLAN FOR HO CHI MINH CITY THAT FOCUSES ON PLAN DOCUMENTS
}

\author{
グェンラム*, 長谷川直樹**, 鈴木 博志***, 兼田敏 之**** \\ Lam NGUYEN, Naoki HASEGAWA, Hiroshi SUZUKI \\ and Toshiyuki KANEDA
}

\begin{abstract}
Since 1986, the Doi Moi policy has triggered the rapid expansion of Ho Chi Minh City. Especially in this paper, we analyze the 1993,1998 and 2010 master plan documents from the perspective of our conceptual framework of their planning system and the evolutionary process of adapting to the internal conditions and external environmental changes. Our findings include for example, two key reasons found among the planning techniques and socioeconomic reasons underlying the revision of the 1998 second master plan, namely the inaccurate population plan forecast and the rapid increase of the population.
\end{abstract}

Keywords : Viet Nam, Ho Chi Minh city, Master plan document, Urban policy, Population allocation, Development axis ベトナム，ホーチミン市，プラン文書，都市政策，人口配置，開発軸

\section{1 研究の背景と目的}

\section{1-1 本研究の背景と目的}

ベトナムは 1986 年のドイ・モイ政策以降、市場経済化を推し進め ており、現在は新興国の一翼を担うに至った。その経済成長ととも に都市部への人口流入、寸なわち都市化が進行し、大都市では都市 基盤インフラの不足などの都市問題が深刻化した。ベトナム南部に 位置し、ベトナム最大都市であるホーチミン市も例外ではなく、ホ 一チミン市では、1993 年に総合建設計画、1998 年に一般建設計画、 2010 年に一般建設計画と 3 回にわたり都市マスタープラン（以降、 マスタープラン、またはプラン) を策定し、それらの問題に対処し ている注1)。

筆者らは、ホーチミン市を対象として、3 回にわたるマスタープ ランの発展プロセスを論じたい。図 1 にそのための発展プロセス研 究プログラムの概念枠組みを示す。プラン図書（プラン文書・プラ ン図面）には、プランの策定・改定のきっかけや計画技術、計画制 度条件、さらには経済社会制度条件などが織り込まれていると考え られる。

筆者らの研究プログラムには、各回プラン策定が係る計画担当者 のヒアリングやベトナム語、日本語、英語文献の体系的サーベイを 含むが、第 1 回、第 2 回プランの策定から時間が経過しているため、 とくにこの時期の実態が明らかにされていない。そのため、この研 究プログラムの第一歩として、各回のプランの文書記述の内容をホ
一チミン市がおかれた当時の計画制度条件や社会経済情勢を踏ま えながら読み解く分析に研究上の意義があると筆者らは考える。

本論文では、1993 年・1998 年・2010 年に公表されたホーチミン市 における 3 回のマスタープラン文書のうち、主にホーチミン市に係 わる記述（以下、プラン文書）を対象として、プラン文書の構成を 比較したのち、策定・改定時の計画制度条件の整理を踏まえて、各 回のプラン文書における計画目標人口と現況人口との突き合わせ、 プラン文書に記載されたホーチミン市 30 キロ圈における開発軸と 実際の市街化方向とを突き合わせて分析検討することにより、一連 のマスタープランの発展プロセスに関する知見を探る。

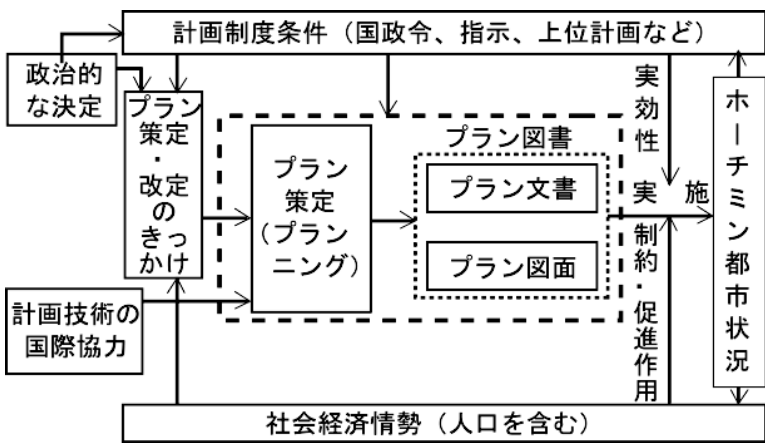

図 1 都市マスタープランの発展プロセス研究の概念枠組み

ドイ・モイ政策以降のホーチミンに関寸る都市計画ならびに政策

\footnotetext{
本論文は, 2012年度・2013年度日本建築学会大会学術講演会にて発表 ${ }^{1011112)}$ した内容に加筆, 再構成したものである。 名古屋工業大学大学院工学研究科 大学院生 $\cdot$ 博士後期課程 $\cdot$ 修士 $($ 工学 $)$

** 名城大学工学部建築学科 講師. 博士 (工学)

*** 名城大学工学部建築学科 教授.工博

**** 名古屋工業大学大学院工学研究科 教授.工博 
に関する既往研究をレビューしたところ、第 2 回プランにかかわる 報告として主に経済・行政の内容を分析したもの ${ }^{1)}$ 見出している。 第 3 回プランへの改定時にかけては、2002 年から日本政府・JICA の技術協力がホーチミン市広域での交通マスタープラン調查や下 水関係の調查などの結果やデータが間接的に第 3 回プラン改定時に 活用されたという経緯がある。この時期には、第 2 回プランの実効 性を述べたもの ${ }^{2)}$ 、運用実態を述べたもの ${ }^{3)}$ に報告が集中している。 また、その他、ホーチミン市については、公共交通 ${ }^{4)}$ 、住宅地開発 に関する計画コントロール ${ }^{5)}$ 、進行市街地における市街化の変遷 ${ }^{6)}$ が報告されている。

\section{1-2 本研究における分析対象}

本研究では、2012 年 7 月から 8 月にかけてホーチミン市建築計画 局、ホーチミン市建設局、ホーチミン市開発研究院において収集し た 1993 年・1998 年・2010 年の 3 回にわたる都市マスタープランの 文書・図面資料のうち、プラン文書にあたる計画書を分析の対象と した。なお、全市的空間構想を示した $1: 25,000$ の図面については参 考にとどめた（表 1 )。

なお、2013 年 8 月から 9 月にかけて、本研究の参考資料 (日本語 英語・ベトナム語）の追加サーベイを行い、都市計画の専門家およ び行政担当者にヒアリングを行っている。

表中第 2 列に示すとおり、プラン文書はいずれも文章と表で構成 された簡素な点に特徴があり、第 3 回文書には相応した数の図が掲 載されているものの、第 2 回文書に関しては図がまったく掲載され てない。また、第 1 回文書は頁数も 145 頁と記述が少ない。なお、 12 の図のうち 11 は一部の行政区についての区・県レベルの地域別 の構想である ( 2 章 2 節で後述)。回を追うごとにプラン文書が充実 してゆくことが示唆される。

表 1 分析対象とした都市マスタープラン文書

\begin{tabular}{|c|c|c|c|}
\hline $\begin{array}{l}\text { 本研究に } \\
\text { おける呼称 }\end{array}$ & 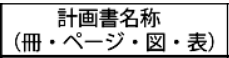 & $\begin{array}{c}\text { 指導機関（策定部局名） } \\
\text { 年 / ( (文書番号) }\end{array}$ & $\begin{array}{c}\text { 参考にした図面 } \\
\text { とスケール }\end{array}$ \\
\hline $\begin{array}{c}1993 \text { 年 } \\
\text { 第 } 1 \text { 回都市 } \\
\text { マスタープラン }\end{array}$ & \begin{tabular}{|c|}
2010 年を目標とした \\
総合建設計画 \\
(Quy hoạch tống thế \\
xây dựng đến năm 2010) \\
全 1 冊 $\cdot 145$ ページ \\
$\cdot 12$ 図・24 表 \\
\end{tabular} & $\begin{array}{c}\text { ホーチミン市人民委員会 } \\
\text { (ホーチミン市建築計画院 } \text { ) } \\
1993 \text { 年 } 8 \text { 月/ }(20 / T T g)\end{array}$ & $\begin{array}{l}2010 \text { 年を目標 } \\
\text { とした空間構想 } \\
\text { (Sơ đổ định hướng } \\
\text { phát triến không gian } \\
\text { đến năm 2010) } \\
1 / 25000\end{array}$ \\
\hline $\begin{array}{c}1998 \text { 年 } \\
\text { 第 } 2 \text { 回都市 } \\
\text { マスタープラン }\end{array}$ & 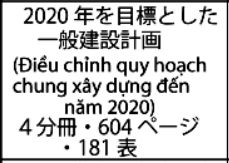 & $\begin{array}{c}\text { ベトナム建設省 } \\
\text { ホーチミン市人民委員 } \\
\text { (ホーチミン市建築計画院) } \\
1998 \text { 年 7月 / }\left(\begin{array}{c}(123 / 1998 / \\
\text { QD-Tg) }\end{array}\right.\end{array}$ & $\begin{array}{c}2020 \text { 年を目標 } \\
\text { とした空間構想 } \\
\text { (Sơ đố định hướng } \\
\text { phát triển không gian } \\
\text { đến năm 2020) } \\
1 / 25000 \\
\end{array}$ \\
\hline $\begin{array}{c}2010 \text { 年 } \\
\text { 第 } 3 \text { 回都市 } \\
\text { マスタープラン }\end{array}$ & 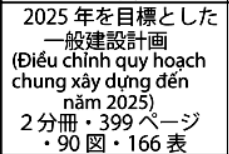 & $\begin{array}{l}\text { ホーチミン市人民委員会 } \\
\text { ホーチミン市建築計画局 } \\
\text { (ホーチミン市開発研究員 } \\
\text { ホーチミン市建築計画院) } \\
2010 \text { 年 } 1 \text { 月/ }(24 / Q D-\Pi g)\end{array}$ & $\begin{array}{c}2025 \text { 年を目標 } \\
\text { とした空間構想 } \\
\text { (Bản đố định hướng } \\
\text { phát triển không gian } \\
\text { đến năm 2025) } \\
1 / 25000\end{array}$ \\
\hline
\end{tabular}

本分析では、2 章において各回のプラン文書の概括、すなわち、 概要と策定・改定理由の記述（1節）、プラン文書の構成（ 2 節） プラン文書中に記載されている検討対象区域（3 節）を説明したの ち、3 章ではとくにプランの策定・改定時に着目して、計画制度条 件の検討 ( 1 節)、社会経済情勢の検討 (2 節)、計画目標と現況人 口との突き合せ (3 節)、プラン文章中に記載された開発軸と実際の 市街化方向との突き合せ (4 節) の検討を行い、3 回にわたる都市マ スタープランの発展プロセスについての知見を探る。

\section{2 各回における都市マスタープラン文書の概要}

\section{2-1 各回における都市マスタープランの概要、策定·改定の理由、}

方針

まず、各回における都市プラン文書の冒頭部に記載された方針、 策定・改定の理由を記す。

\section{（1） 1993 年第 1 回都市マスタープラン}

第 1 回都市マスタープランは 1993 年 8 月に首相決定（Quyết Định Thủ Tướng) を受けたもので、2010 年を目標年次とし、ホーチミン 市をべトナム最大の工業生産地ならびに経済・貿易・科学技術の中 心地として開発する方針であった。

プラン策定の理由として、「1982 年にベトナム共産党中央政治局 決議（Nghị Quyết Bộ Chính Trị）（No:01NQ-TW)においてホーチミン 市は国家の政治・文化・経済の中心地であることがはじめて認めら れた。1991 年の政府示達 (Chỉ Thị Chính Phủ) (No：19-CT)において『心゙ トナムの都市部では、経済が衰退し失業者が多く住宅問題が深刻化 し、生活環境が悪化するとともに公共施設・インフラ整備が不足し ているが、土地・建設のライセンス交付が放任されたため都市部の 建築景観が無秩序に混乱し、都市開発について戦略的な計画が久如 している。そのため首都のハノイ市とホーチミン市では緊急に都市 計画を策定することが求められた』(p.8)」と記載された。

\section{(2) 1998 年第 2 回都市マスタープラン}

第 2 回プランは 1998 年 7 月に首相決定を受けたもので、 2020 年 を目標年次とし、ホーチミン市を国内および東南アジアの経済・貿 易・文化・観光・科学技術の中心地機能を持つ都市とし、かつ個性 ある都市づくりを展開する方針を掲げた。

プラン改定の理由として、「1993 年に第 1 回プランを踏まえて、 経済成長・人口規模・土地利用・インフラ整備・空間構想・都市建 築について政策を実施してきたが、現在では計画の内容がそぐわな いものになった。既成市街地の再整備ならびに郊外の開発を推進す るとともに、ホーチミン市と近隣各省における新都市の計画とを整 合することが求められている。同時にベトナム都市総合開発計画方 針、南部重点地域の経済開発計画といった上位計画やホーチミン市 社会経済の開発方針との整合性を保つため、第 1 回プランの改定が 必要になった (pp.1-2)」と記載された。

\section{(3) 2010 年第 3 回都市マスタープラン}

第 3 回プランは 2010 年 1 月に首相決定を受けたもので、 2025 年 を目標年次とし、環境保護 - 国防保安 ・歴史的建築物の保全と持続 可能な開発を促進寸るとともにホーチミン市を東南アジアの工業・ サービス・科学技術の中心的都市として成長させる方針であった。

プラン改定の理由として「2009 年にベトナムで都市計画法が策定 され、そのなかで、都市マスタープラン策定後、5 年ごとに定期的 な改定が義務付けられた。前回プランに従い、人口配置・社会経済・ 空間構想・区域別の構想・インフラ整備についての政策を実施して きたが、現在では内容がそぐわないものとなった。また、検討対象 区域に近隣各省を含めたにも関わらず、実際の建設において検討対 象区域は重要視されていない。現在、近隣各省との連携を強めて環 境保護・インフラ整備の整合・就労者の再配置を行うことが必要で ある。2002 年のベトナム共産党中央政治省決議（No:20-NQ/TW）を 受けた社会経済開発計画では、2010 年を目標として特にインフラを 一括して整備するとともに、都心域にある港湾を郊外に移動するこ 
とが求められた。また、2008 年には経済の急激な発展に対応してホ 一チミン圏を対象とした戦略ビジョンが策定されたため、第 2 回プ ランを改定する必要が生じた（pp.1-2）」と記載された。

\section{2-2 各回における都市マスタープラン文書の構成の変遷}

各回におけるプラン文書の構成を図 2 に整理して示す。各回のプ ラン文書は（a）目的（法律上の位置づけ、計画の目標、改定理由）、 （b）都市の現状と課題（市街地形成の歴史、自然条件、人口・雇用、 土地利用、都市基盤などを含む)、(c) 計画の骨子（検討対象区域、 人口配置、主な社会経済指標、都市における建設用地の面積 ・指標 などを含む)、(d) 実施方策（空間構想，都市基盤施設などを含む）、

(e) 事業プログラムの 5 大項目より構成される。

ここでは、（d) 実施方策における空間構想のうち、全市的構想 ( định hướng phát triển không gian thành phố city wise spatial vision policy) と地域別また区域別の構想 (định hướng phân khu chức năng 、plan by the area）の 2 つの側面を取り上げ、計画技 術上の発展プロセスに言及する。

\section{（1） 1993 年第 1 回都市マスタープランの構成}

まず、第 1 回プラン策定時の全市的構想として、「市全域において 3 つの工業・商業・公共施設の配置方針を策定するとともに、区 県ごとに空間構想を策定した」(p.77-90) との記述がみられる。

第 1 回プランにおける地域別の構想について述べるならば、当時 18 の行政区・県 (Quận・Huyện) で構成されていたホーチミン市のう ち 13 区（1 区・3 区・ 4 区・6 区・8 区・11 区・Phu Nhuan 区・Go Vap 区・Tan Binh 区・Binh Thanh 区・Cu Chi 県・Binh Chanh 県・Hoc Mon 県）を重点「区・県」として、11 の構想図とともに区・県レベルの
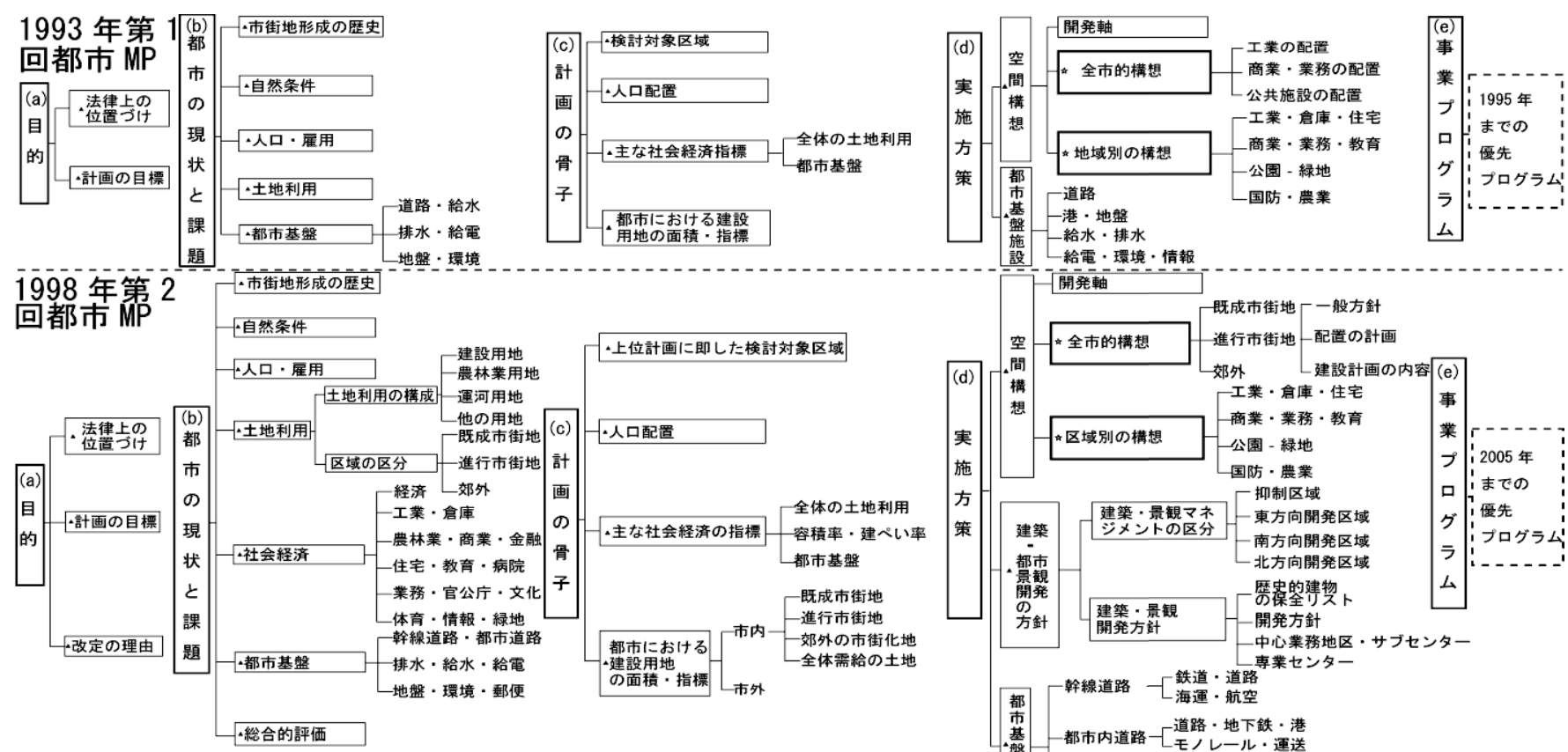

給電・環境・情報
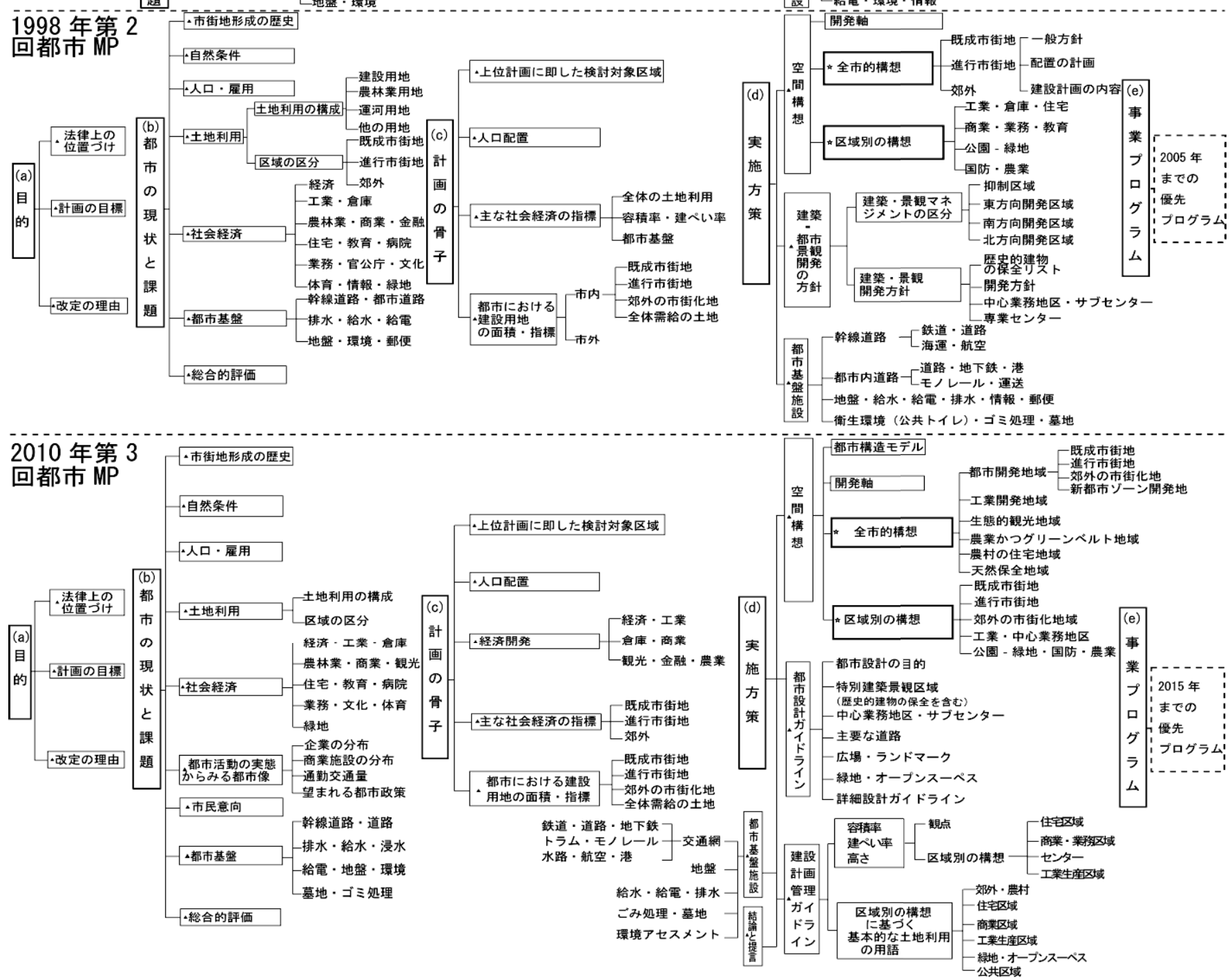

図 2 各回の都市マスタープランの構成 
地域別の構想が掲載されていた (p. 91-120)。

\section{(2) 1998 年第 2 回都市マスタープランの構成}

第 2 回プラン文書における全市的構想として、新たに「既成市街 地 (Khu Vực NộiThành Cũ)」「進行市街地 (Khu Vực Mới Phát Triển)」 「郊外 (Khu Vực Ngoại Thành)」の 3 つの区域が設けられ (p. 16)、第 3 回プラン文書においても範囲指定が若干変更されながらも継続し ている(p.16、図 3 参照)。

第 2 回プランでは、都心部の 12 の区が既成市街地に指定された。 また、1997 年政府政令 (Nghị Định Chính Phủ) (No：03/CP)により新 設された 5 つの区（2区・7 区・9 区・12区・Thu Duc 区）が進行市 街地に指定され、残りが郊外と指定された。2003 年政府政令 （No：130/2003/NĐ－CP）によってTan Binh 区から Tan Phu 区が分離 し、Binh Chanh 県 から Binh Tan 区が分離したが、その際、Binh Tan 区は進行市街地の区域に加えられた。残りの部分は郊外と指定され ている(図 7 の 1 段参照)。

第 2 回プラン策定時の全市的構想は、「市全域において工業・商 業・業務・緑地・国防・農業の規模、配置の方針を策定した」(p. 40-47)。 さらに、住宅用地に関する内容では、「区域別に高さ、指標、建蔽率 の方針を策定し、また既成市街地において住宅用地の建蔽率を低減 するため、川沿いのスラム住宅のクリアランスを実施する」方針が 記載された (p. 49)。

第 2 回プラン策定時には、区域別の構想として「前述の 3 つの区 域別の方針を策定するとともに当時ある 22 の区・県すべてにおいて 土地利用用途ごとの規模・性質・指標を策定した」(p. 64-104)。

\section{(3) 2010 年第 3 回都市マスタープランの構成}

次に第 3 回プランについて述べる。このプランの特徵としては、 都市活動の実態にみる都市像や市民意向を総合的評価に含めるなど 計画調查に充実がみられるほか、全市的構想については「区・県の 行政区界や 3 つの区域範囲を超えて、土地利用ごとに機能的ゾーニ ングの方針を策定している」（p.147-148）。また、（d）実施方策にお ける「建設計画管理ガイドラインに容積率・建蔽率・高さといった 建築規則の基本的な考え方が示された」(p.179-184)。

第 3 回プランの地域別の構想では、「3つの区域の各々において区 域別の構想及び土地利用ごとの要件規模を示したほか、その各々に 機能的ゾーニング」を策定したと記載された (p. 148-160)。

ここで、筆者らは 3 回のプラン文書にわたる掲載した全市的構想、 地域別また区域別の構想の内容について解釈を試みる。

第 1 回プランでは、全市的構想については充実しておらず、また、 市場経済初期に揚げられた臨時措置である建設計画が重点として位 置づけられたと解釈できる。このプランはのちに「全市域において 交通のフレームワーク・インフラ整備の仕組み・都市基盤用地、公 共用地・国防の設定が欠如している」注 4) と指摘されたことにもみ られる。

第 2 回プランでは、全市的構想については第 1 回プランより内容 が充実したほか、とくに住宅用途を厳密にコントロールする意図が あったとみられる。これは既成市街地における人口抑制策に反映さ れると考えられる (3 章 3 節で後述)。第 1 回プランにおける区・県 レベルの地域別の構想は第 2 回プランで区域別の構想へと拡大した と捉えることができ、ゆえに、第 1 回プランに比べて前進したがみ られる。
第 3 回プランでは、全市的構想については 2009 年都市計画法に基 づいて機能的ゾーニングの方針が記載され、大幅に拡充された点に 特徴がみられる。区域別の構想については拠点的土地利用の用途を 策定するなどの改善がみられる。

\section{2-3 各回の都市マスタープラン文書にみる検討対象区域の変遷}

市が策定したプラン 3 回ともホーチミン市全域が計画対象区域で ある。しかし、プラン文書には、市域外の地名も言及されている。 これらの言及された地名からプラン策定時に検討された地理的範囲 (以降、検討対象区域) を同定することができる。検討対象区域の 変遷を図 3 下に整理する。

第 1 回プラン文書では、ホーチミン市区域外の記述はなく、検討 対象区域はホーチミン市全域であった。

第 2 回プラン文書では、同時期に策定された空間的上位計画にあ たるベトナム都市総合開発計画方針における南部ならびに南東部の 経済重点地域のうち、ホーチミン市を中心とした 10,000ha が検討対 象区域とされた。より具体的には、ホーチミンから 30-50km の圈域 が言及されたほか、ホーチミン市外の 44 の都市が指定され、行政区 域としてはホーチミン市のほか 6 つの省が記載された (pp. 4-5)。

第 3 回プラン文書では、第 2 回プランの検討対象区域のほか新た

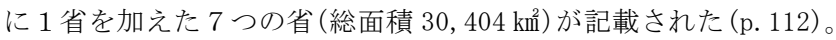

これは検討対象区域がベトナム建設省による上位計画の 2008 年 ホーチミン圏建設計画の区域注3) と一致している。
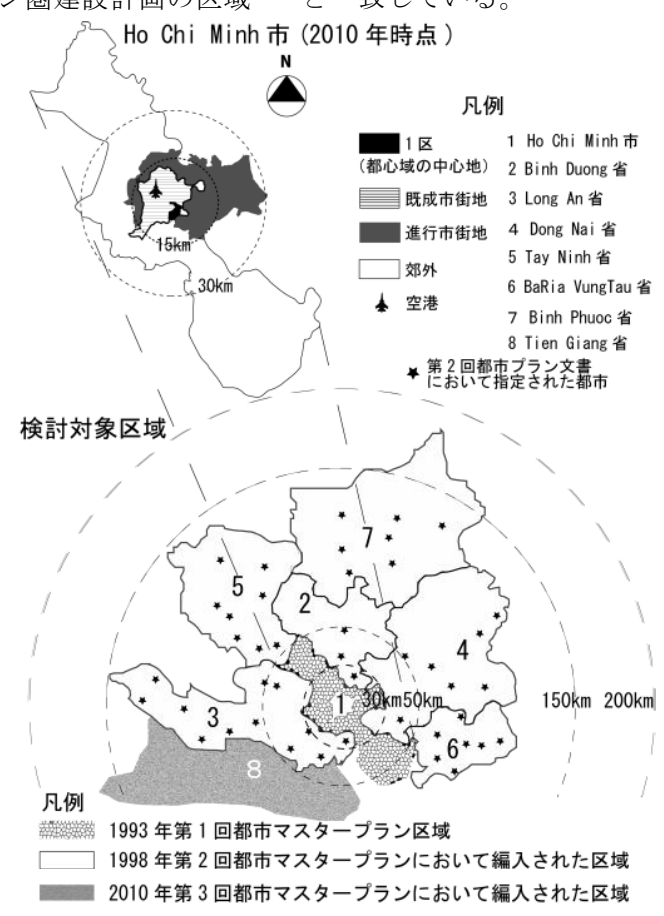

図 3 各回のプラン文書に記述されている検討詨象

\section{3 プラン策定・改定時を巡る諸条件の分析検討}

2 章では、プラン文書の内容について説明したが、 3 章では、各回 のプラン文書を策定・改定時における諸状況のデータや資料を突き 合せて分析検討する。

\section{3-1 各回のプラン策定・改定時における計画制度条件の検討}

図 4 下に、第 1 回プラン策定に遡る 1987 年から第 3 回プラン改定 に至るさらに 2014 年までの期間について、国土に関する法律・都市 
づくりに係る主なガイドライン・都市マスタープランに係る主な上 位計画・関連計画といった計画制度条件を示す。さらに、各回プラ ンにおいて主な空間構想の発展プロセスの検討を行う。

\section{（1） 1993 年第 1 回プラン策定を巡る計画制度条件}

第 1 回プラン策定時においては、プラン文書の冒頭で述べられた 制度条件（2 章 1 節に既述）や1987 年発布の土地法に加え、1987 年建設省決定の「ベトナム設計標準 (都市建設計画)」といったガイ ドラインが与えられていたが、このガイドラインでは、「人口規模 30 万人以上であるホーチミン市は大都市として分類され、都市マス タープラン策定に関するガイドラインはプランの目標が 15 25 年間、

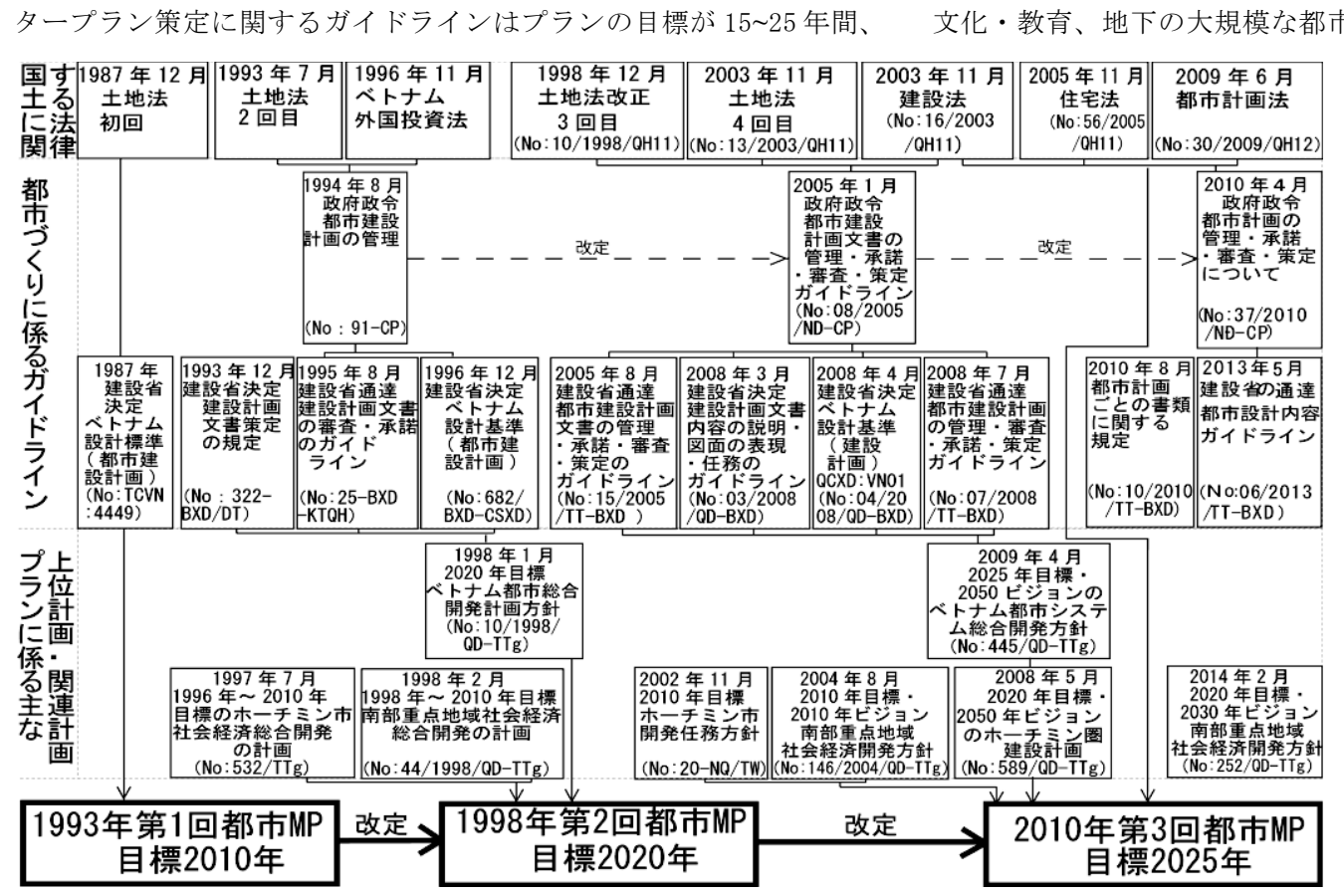

図 4 各回都市マスタープラン策定・改定を巡る計画制度条件 p. 4)。

それを受けて、ホーチミン市と近隣各省との関係が大局的な視点 注 5)を持つようになり、検討対象区域の拡大の動機となったと考え られる。また、筆者らのヒアリングによると、ホーチミン市の都市 計画局の関係者は「ホーチミン市の既成市街地エリアを拡大寸るた めに、第 2 回プラン改定が必要となった」と述べている注6)。

\section{（3） 2010 年第 3 回プラン策定を巡る計画制度条件}

その後、2005 年 1 月に政府決定（No:08/2005/ND-CP）により、空 間構想では「各センターシステムの商業・行政・政治・サービス・ 文化・教育、地下の大規模な都市基盤」が規定された。 将来の都市拡大のために準備用地が必要で、また、 5 年間の優先プ ログラムを設ける必要であった。プラン策定の以外に工業団地・住 宅・交通の設計指標・標準の内容」が規定されていた。第 1 回プラ ン策定においては、ガイドラインを踏まえたものの、その内容が充 実していなかったため、前述したとおり空間構想の記載が不十分で あったと考えられる。

また、上位計画や関連計画が整備されていない状況であったため、 計画対象区域がホーチミン市のみとなったことが分かる。

\section{（2）1998 年第 2 回プラン策定を巡る計画制度条件}

1993 年 1996 年の間に建設省を中心に中央政府は都市づくりの一 連のガイドラインを策定し、その中の 1995 年建設省通達（№： 25-BXD-KTQH）により、空間構想の策定では「開発軸、区域別の構想・ 土地利用、建築配置、歴史的・景観保存地域、建設禁止・抑制地域、 都市整備」などが規定された。

そのため、第 2 回プラン策定時にはこれらのガイドラインを踏ま えて、ホーチミン市を対象とした社会経済開発計画などが整備され たことほか、上位計画の「1998 年ベトナム都市総合開発計画方針 （No：10/1998/QD-TTg）により、近代化・工業化に向けてハノイ市、 ホーチミン市、ハイフォン市、ダナン市では、全国において主な経 済活動の核心とした経済の再改築 ・構造改革 - 向上及び北部・中部 南部のバランスをとって都市網を再整備する」と記された(第 2 編
2008 年 3 月の建設省決定 (No:03/2008/QD-BXD) では「プ ラン策定・改定に関するガイド ライの内容が拡充したほか、区 域別の構想・公共空間・主な都 市軸・オープンスベース・公園・ 水面・近隣地域のインフラ整備 に関する都市構造モデルを策定 する」ことが規定された。

2008 年 7 月に建設省通達 (No:07/2008/TT-BXD) により、 空間構想では、「開発ビジョン・ 主な各戦略的開発の方針、都市 開発目標の段階に応じて土地利 用・都市基盤の指標が適切に設 定し、土地利用用途の整合性」 が求められることになった。 2009 年にはじめて中央政府 によって都市計画法が法制化さ れた。そのため、第 3 回プラン改定時には、それらのガイドライン を踏まえながら、さらに、南部重点地域の社会経済開発方針などが 整備されたため、都市計画法に基づく充実した記述になったと考え られる。

その後、2010 年 4 月政府政令 (No: 37/2010/ND-CP)により、空間 構想のなかに、「市全域において工業・農業・林業・生態・保存地域 等の機能・性質・規模・開発方針」という全市的構想がはじめて規 定された。

以上、計画制度条件に基づいてプラン策定・改定時の発展プロセ スを整理・説明した。計画制度条件が改善されたことによって、各 回プランにおける空間構想の内容の記述が増したと考えられる。

\section{3-2 各回のプラン策定・改定時における社会経済情勢の検討}

図 5、第 1 回プラン策定に遡る 1990 年から第 3 回プラン改定に至 る 2010 年までの期間について、ホーチミン市における一人当たり所 得と国民一人当たり所得との比や人口純増減とくに人口純流入とい った社会経済指標を示す。

ホーチミン市の経済は一貫して順調な成長を遂げ、国民一人当た り所得に対する市民一人当たり所得の比はつねに 2.4 倍から 2.65 倍を保ち続けた。1993ー1998 年には純流入が鈍った時期もあったが、 概ね一貫して増加している。従って、国民一人当たり所得より市民 
一人当たり所得の比が高いため、人口流入を呼び込む典型的な都市 化現象といえる。具体的に各回プラン策定・改定された時期に応じ た社会経済情勢を検討する。
は 388 万人と増加を見込むものの、以降 2020 年までは 360 一 400 万 人と抑制を示して、一方、「進行市街地」「郊外」はあわせて現況 161.3 万人、 2005 年に 232 万人、 2020 年に 520 - 640 万人と人口増加の受

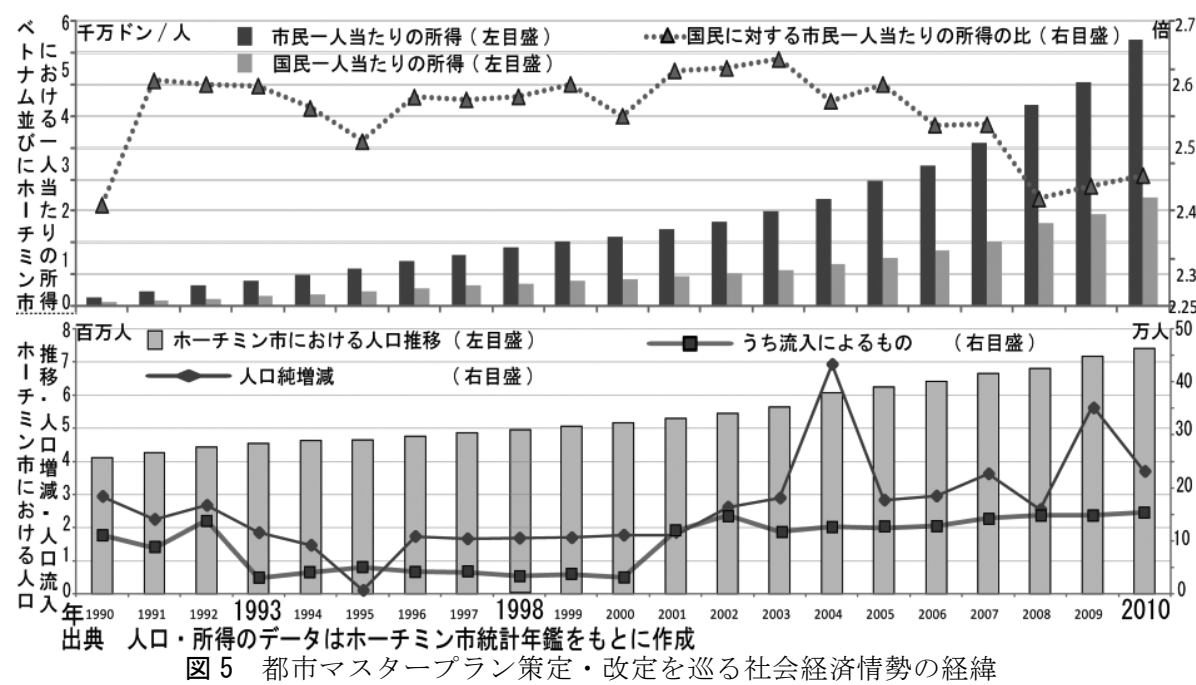

第 1 回プラン策定時にドイ・モイ政策後の社会経済が不安定な時 期で、将来の経済発展などを誘導する位置づけにあったと考えられ る。

第 2 回プラン改定時にドイ・モイ政策の経済効果等が現れ、ホー チミン市の人口や市民一人当たり所得が着実に増加している時期で あった。人口増加や経済発展に合わせた都市の発展を計画的に進め る位置づけにあったと考えられる。

第 3 回プラン改定時に急激な人口増加や経済発展に合わせた都市 の発展を計画的に進める位置づけにあったと考えられる。

\section{3-3 計画目標人口と現況人口との突き合わせにみるプラン改定の 要因検討}

この節では、第 2 回・第 3 回プラン改定時において, 前回プラン 文書で記載された計画目標人口とその当時の現況人口との突き合わ せを行うことによって、プランの策定・改定の要因についてより分 析検討する。

各回のプラン文書に記載された現況人口ならびに計画目標人口を 図 6 のグラフに示す。

1993 年に策定された第 1 回プラン文書では、ホーチミン市の現況 人口 454 万人に対して 2010 年の計画目標人口として 500 万人が掲 げられた。年間増加率に換算すると $1.39 \%$ ありり、自然増を見込ん だものの社会増つまり人口流入を見込んだものではなかった。その ため、すでに 1998 年には現況人口は約 496 万人に達した ${ }^{7)}$ 。これは 年間増加率に換算して $1.79 \%$ でり、第 1 回プランが想定しなかっ た都市化に直面した。さらに、人口計画の計算が不正確なため、第 1 回を改定する必要があったと考える。

第 2 回プラン文書では、全市の計画目標人口は 2005 年の中間目標 として 620 万人、 2020 年の最終目標として 900 - 1000 万人が掲げら れた。これは年間増加率に換算すると $2.52 \%$ 3. $24 \%$ あり、都市化 による人口流入を見込んだものである。

またこの回から区域別人口も掲げられており、これをみると、「既 成市街地」は 1998 年現況人口が 334.5 万人に対して、2005 年まで
け皿とされた。この想定は都市化の次の段 階としての郊外化を見込んだものと解勫寸 ることができる。

しかしながら、2010 年時点の現況人口を みると、第 2 回プランにおける「既成市街地」 は 390.3 万人と人口抑制の方針がマクロ的 には概䄈成されているの に対し、「進行 市街地」は 215.7 万人と人口増加が想定以上 に進行し、最終目標年次よりはるか以前に 「進行市街地」の収容人口（220－240 万人) が超過することが明白な趨勢となった。

そのため、第 3 回プランでは、「既成市 街地」の計画人口を 2015 年時点までは 432 万人に緩和し、そののち 2025 年の最終 目標時点までに 400ー450万人と抑制基に

転じる方針となった。一方、「進行市街地」については 2015 年時点 までは人口維持基調に、それ以降 2025 年までは人口収容を肯定する ものと読み解くことができる。また、「郊外」についてはこれまでの 趨勢を一貫して肯定して人口収容基調の方針が掲げられている $(2010$ 年現況では 133.6 万人、 2015 年中間目標時点では 164.7 万人、 2025 年最終目標時点では 260 - 305 万人)。

これらの区域別計画目標人口の修正から考えると、これらが第 3 回プラン改定の一つの要因になると考えられる注6)。

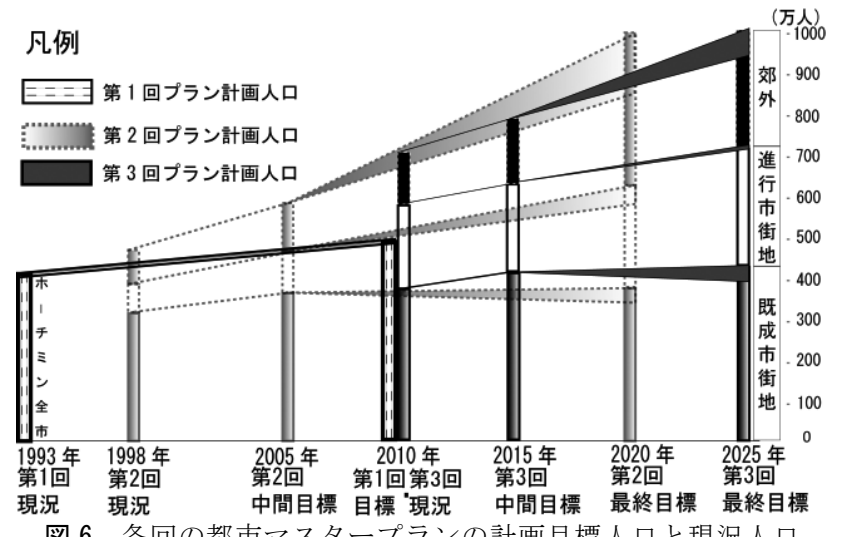

図 6 各回の都市マスタープランの計画目標人口と現況人口

\section{3-4 プラン文書の開発軸と実際の市街化方向との突き合わせに みるプランの実効性}

各回のプラン文書には、図 2 のとおり、(d) 実施方策の大項目にお ける空間構想の項目に開発軸注》に関する記述がある。

この節では、各回のプラン文書に記載されている開発軸と実際に 市街地の進行との比較検討を行い、各回のマスタープランにおける 実効性についてマクロ的に考察する。この分析作業のために、1986 年から 2010 年にかけてのホーチミン市 $30 \mathrm{~km}$ 圈の 4 期にわたる各行 政区別の人口増減を集計して図 7 に示した。

寸でに 1993 年の第 1 回プラン文書において、開発軸についた記述 された文言がみられる(p.10)。この分析では、各回プラン文書が記 
載した開発軸について都心域の第 1 区を中心とした際の方向に着目 する。第 1 回プランにおいては、おもに北東方向に開発軸が設けら れていた。プラン策定時にあたる 1986 年一1992 年には北東方向を 中心に北西方向から南東方向にかけての $10 \mathrm{~km}$ 圈以遠で緩い増加を 示しており、開発軸の設定はこの趨勢を強化する意図があったと考 えられる。

しかしながら、1992 年-1998 年には北西方向 (5-15km 圈) ・北東 方向 (10km 圈以遠) ・西方向 (10km 圈以遠) の順で人口が増加して おり (図 5 第 3 段)、第 1 回プランに示された開発軸以外の北西方向・ 西方向においてマスタープランと整合しない人口増加を許容する結 果となった。

1998 年第 2 回プランでは、開発軸は第 1 回における北東方を加え て、新たに南東方向が記載されている(第 2 編 p. 39 )が、この記載は、 当時の現状を肯定しつつ、当時市街化の余地が残された方向に開発 を促進する意図があったと考えられる。

1998 年から 2010 年について概括するならば、西方向 (15km 圈以 遠 $) \cdot$ 北西方向 $(5 \mathrm{~km}$ 圈以遠 $) \cdot$ 北東方向 $(15 \mathrm{~km}$ 圈以遠 $) \cdot$ 南東方向 $(5 \mathrm{~km}$ 圈以遠)の順で人口が増加した。ただし、開発軸が設けられた南東方 向は他の方向に比べてその増加は大きくはない。このことは、第 2 回プランにおける開発軸と実際に市街化の進行方向とが整合しなか ったことを示している。とくに、3 章の 3 節の前述したように第 2 回策定時に既成市街に人口抑制を策定したが、図 7 の 3 期の 1998 年から 2004 年に至る既成市街地において実際の人口増減を確認寸 ると、中心とした既成市街地の 1 区・3 区・ 4 区・ 5 区・ 6 区・10 区・ 11 区・Phu Nhuan 区は人口を減少したが、図 7 の 4 期の 2004 年か ら 2010 年に至る既成市街地の 4 区・5 区・ 6 区・11 区を逆に増加し た。これは、第 2 回改定時に既成市街地の人口抑制が維持できない とみられる。従って、第 3 回策定時に既成市街地の計画人口を抑制 基調に転じる方針となったと考えられる。

ところで、注目す心゙きは、第 2 回プランにおいてはじめて、各開 発軸に応じた進行市街地に 4 つのサブセンターが設けられたことで ある。

なお、第 3 回都市プラン文書では、南東方向・東方向の二つを記 載している (p. 146)。第 3 回プランでは、新都市ゾーン開発 5 つとサ ブセンター 5 つが設けられているが、東北方向と南方向のサブセン ターについてはこの間にサブセンターから新都市開発ゾーンに格上 げされている。一方で、南東方向は、市が開発を強調した開発軸が 策定したが、ここでは、地盤が弱く、河川の汇濫も多いため、これ らの克服が課題となると考えられる注8)。

2008 年 3 月建設省決定（No:03/2008/QD-BXD）では、都市構造ビ ジョンがはじて求められたため、第 3 回プランでは、 $15 \mathrm{~km}$ 半径の都 心域が設定され、西側への市街地拡大と新都市ゾーン開発およびホ ーチミン市域の外側に衛星都市を配置されることにより、多極分散 型の都市構造が提示されることになった（p. 145）。

\section{4 結論}

3 回にわたるプラン文書のうちホーチミン市に関する記述を対象 に行った分析・考察よりプラン改定の要因と計画技術上の発展プロ セスについて以下の知見を得た。

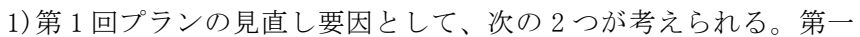

Ho Chi Minh 市の区・県区分

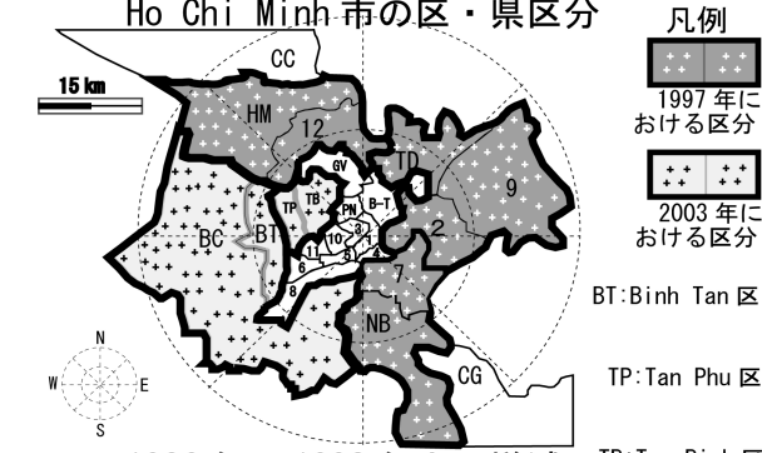

1986 年 1992 年人口増減 TB: Tan Binh区

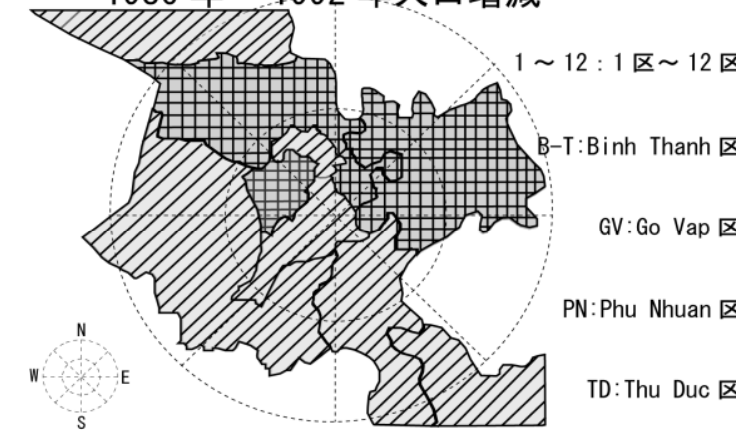

第 1992 年 1998 年人口増減

HM: Hoc Mon 県

NB: Nha Be 県

CC:Cu Chi 県

CG：Can Gio 県 BC: Binh Chanh 県
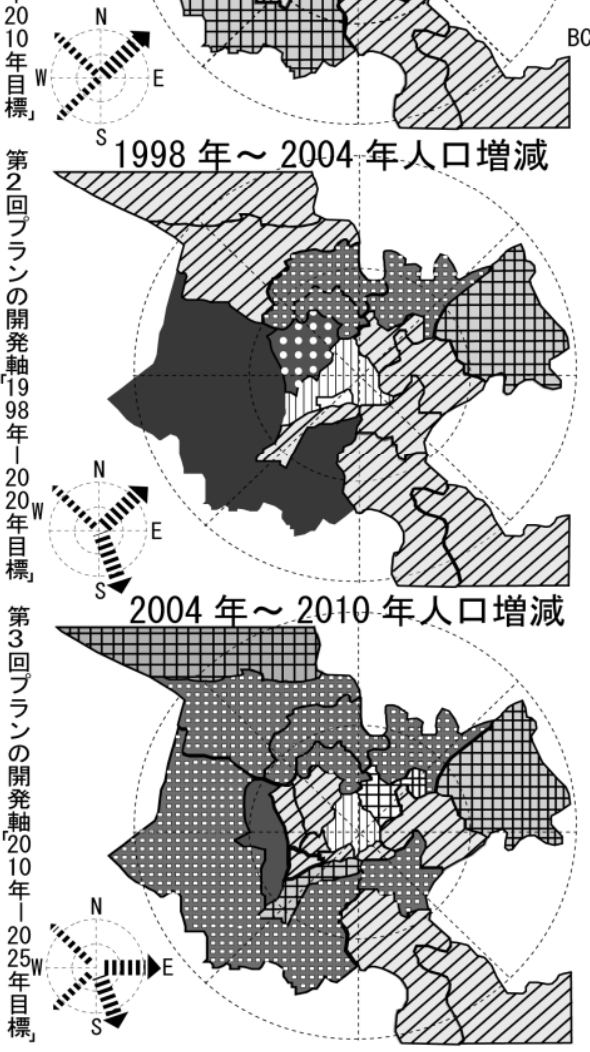

25 万以上増

$20 \sim 25$ 万增

$:::::$ $15 \sim 20$ 万增 $10 \sim 15$ 万增

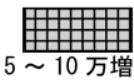

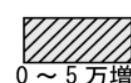
|

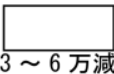
"II!I!IIII サブ開発軸

図 7 ホーチミン市 $30 \mathrm{~km}$ 圈における 1986 年-2010 年 の人口増加及び各回プランの開発軸 
は、ホーチミン市をとりまく社会経済情勢の変化、とくに、想定 以上の人口増加であった。第二は、第 1 回プランにおける計画目 標人口の予測が不正確であった。そのため、1998 年時点にすでに 市域人口が第 1 回プランの 2010 年の計画目標を超える趨勢にあ った。

2) 第 2 回プランでは、既成市街地の人口抑制を目標に掲げ、川沿い のスラム住宅クリアランスの実施方針を記載するなど、既成市街 地の住宅用地のコントロールを目指した。しかし、既成市街地の 人口が抑制しきれなかったため、区域別の計画目標人口を再修正 することが第 3 回プラン改定の一つの要因になったと考えられる。 3)また、第 3 回プラン改定時は、想定以上の人口の郊外化も進行し ていたため、既成市街地への人口の再収容を許容する政策に転じ ることになった。その際、新たに発効した都市計画法に基づいて、 空間構想においては全市域対象に区域別に機能的ゾーニングの方 針を掲げた。

4) 第 1 回・第 2 回のプランでは、プラン文書で掲げられた開発軸と 実際の市街化方向が整合していないことを分析から確認した。開 発軸と実際の市街化方向についてはより詳細な分析が今後の課題 であると考える。

5) ホーチミン市はこの時期つねに想定以上の人口増加を経験したが、 そのためホーチミン圈域全体のプランニングの重要性が認識され るに至り、上位計画などの計画制度条件が整備されていった。検 討対象区域の順次の拡大はこれを示唆するものである。

\section{謝辞}

本稿を進めるにあたり、ホーチミン市開発研究院の Du Phuoc Tan 氏・建築計画局の Nguyen Anh Tuan 氏と Nguyen Hong Van 氏・建設 局の Nguyen Hai Ly 氏にヒアリングした方々に多大なる御協力をい ただきました。深く感謝いたします。

\section{注}

注 1)ベトナムの総合建設計画、一般建設計画は日本の都市マスタープランと 類似の内容である。本稿では既往研究での位置づけをふまえて、都市マス タープランの名称を使用する。

注 2) 現在のホーチミン市建築計画院は、当時のホーチミン市の建築士長・都 市建築および建設計画研究院である。

注 3) 2008 年ホーチミン市圈建設計画の計画区域はホーチミン市、Binh Duong (ビンズオン)省、Binh Phuoc (ビンフォック)省、Tay Ninh (タイニン) 省、Dong Nai（ドンナイ)省、Long An（ロンアン)省、BaRia-VungTau(バリ アーブンタウ)省、Tien Giang(ティンヤン)省であった。

注 4)第 2 回プラン策定を担当した当時のホーチミン市建築計画院長の An Dung 氏の記事によれば、ホーチミン市における都市建設計画策定及び改定 の提案、建設省決定（No:322/BXD-DT）に基づく詳細プランとプランの問題 があったため、改定・廃棄を提案したほか、第 1 回プラン策定時にその問 題があったと記されている。(参考文献 13、pp. 35-37 を参照)。

注 5) 第 2 回プラン改定時には政府建築コンサルティング協会の報告書（№： 27/TVKT ）によれば、ホーチミン市と近隣各省との関係が大局的な視点を 持つように、検討対象区域を提案したと記されている。しかし、2008 年 3 月の南部農村都市計画院の会議のホーチミン圈建設計画策定時（№： 589/QD-Ttg) において、代表者は各々が行政範囲にこだわり、全域の連帯を 欠き、相互の補強が久如していると発言した。(参考文献 18 を参照)。

注 6) 2014 年 2 月 10 日-14 日にホーチミン市開発研究院の副院長 Du Phuoc Tan 博士及びホーチミン市都市建築局の建築研究センターの副センター長の Nguyen Anh Tuan 博士にヒアリングを行った。計画人口の修正が第 3 回プ ラン改定への要因にあったか否かについて問うたところ、両氏とも否定の 回答は得られなかった。とくに Tan 氏は「第 1 回策定時に当時の都市計 画担当局は計画人口を予測することが不正確であったため、ホーチミン
市の既成市街地エリアを拡大寸る必要であるため、第 2 回を改定するとな った」と述べた。

注 7) 各回プランにおける開発軸の意味を述べるならば、土地利用状況・自然 の条件に応じて、市街地の拡大、新都市の開発、社会インフラ整備・都市 基盤などの計画的な開発を誘導する地理的・空間的な方向の指示である。

注 8) ホーチミン市の地形は北東地方と北西地方に低い丘陵が並び、西北方向 の $\mathrm{Cu}$ Chi から南東方向の Can Gio 県にかけて徐々に低くなり、Nha Be 県、 Can Gio 県の海抜は $0 \sim 2 \mathrm{~m}$ で地盤が弱く、潮浸水の影響が大きい。

\section{参考文献}

1)Huong Ha,Tai-Chee Wong : Economic reforms and the New Master Plan of Ho Chi Minh City,Viet Nam,Implementation issues and policy recommendations,Kluwer Academic Publishers,Printed in the Netherlands GeoJournal49,pp.301-309,1999-2000.

2) 松村茂久: ベトナム国ホーチミン市における都市計画マスタープランの実 効性向上の試みホーチミン市都市計画マスタープラン改定調査プロジェク トの分析を通じて, 日本都市計画学会都市計画論文集 N0. 44-2, pp. 1524,2009. 10.

3) 松村茂久、岩田鎮夫 : ベトナム・ホーチミン市における都市計画マスター プランの運用実態に関する研究, 日本都市計画学会都市計画論文集, No393,pp. 277-282,2004. 10.

4) 国際協力機構（JICA）: The Study on Urban Transport Master Plan and Feasibility Study in Ho Chi Minh Metropolitan Area (HOUTRANS), 2004.

5)Nguyen, T. A. : The Study of Land Development Mechanism in Vietnam; the Case Study of Development Control in Residential Development Projects in Hanoi and Ho Chi Minh City,Ph.D. Thesis submitted to the University of Tokyo,2007.

6) Nguyen Thi Thuy : 1975 年から 1996 年にかけてホーチミン市の都市化の変 遷に関する研究, 8 区,BinhThanh 区,TanBinh 区,GoVap 区の事例を通じて,ホー チミン国家大学・人文科学大学,博士論文,2004 (Qúa trình đô thị hóa ỏ thành phố Hồ Chí Minh từ 1975 đến 1996 . Trường họp các quận 8, Bình Thạnh, Tân Bình, Gò Vấp) .

7) 1976 年 1981 年, $1989 \cdot 1994 \cdot 1996 \cdot 1997 \cdot 1998 \cdot 1999 \cdot 2000 \cdot 2001$. $2002 \cdot 2003 \cdot 2004 \cdot 2005 \cdot 2006 \cdot 2008 \cdot 2009 \cdot 2010$ 年 Statistical Yearbook of Hochiminh city,Statistical Office of Hochiminh city.

8) Urban Planning Institute of HCMC and Nikken Sekkei : The study on the adjustment of HCMC master plan up to 2025,final report. Prepared for the Ho Chi Minh City People"s Committee,2007.

9) 松村茂久,澤木昌典,柴田祐 : 移行経済下のベトナムにおける都市計画法の 展開と課題,ホーチミン市におけるゾーニング計画及び建築管理ガイドラ イン制度の適用事例の分析を通じて, 日本都市計画学会,pp. $541-546$, 2012. 10.

10) NGUYEN LAM,長谷川直樹,鈴木博志 : ベトナム・ホーチミン市における都市 政策の変遷に関する研究 その1,都市計画マスタープランの位置づけと将 来都市構造の変遷過程、日本建築学会大会学術講演梗概集. F-1, 都市計画, 建築経済・住宅問題,pp. 691-692,2011.

11) NGUYEN LAM,長谷川直樹,鈴木博志 : ベトナム・ホーチミン市における都市 政策の変遷に関する研究 その 2 , 都市計画マスタープランの土地利用計画 の変遷過程,近畿支部建築学会, 2012 .

12) NGUYEN LAM,長谷川直樹,鈴木博志 : ベトナム・ホーチミン市における都市 政策の変遷に関する研究その 3 ,都市計画マスタープランの人口計画と土 地利用計画,日本建築学会,2012.

13) ホーチミン市計画の評価・論理・研究特集、ホーチミン建築計画院及び建 設省の建築雑誌出版社 (Lý luận phê bình nghiên cứu kiến trúc thành phố Hồ Chí Minh ), 1998. 11.

14) Ha Van Hue : The changing ideological basic of planning practice in HaNoi, Vietnam, Deakin University, Master's Thesis, 2000.

15) Naohiro Kitano : Recent Study on Urban Sector Issues In VietNam -Urban Development And Housing And Urban Public Transportation, JBIC Review ,No.1,p.129,2009.

16) Dean Cira: Vietnam Urbanization Review Technical Assistance Report, World bank, pp17-177,2011.

17) 国土交通省国土計画局: アジア地域等の地域政策に係る動向分析および支 援方策などに関する調查,ベトナムの国土政策事情の報告書,2011.3.

18) http://www. qdnd. vn/qdndsubsite/vi-VN/61/28088/print/Default. asp 